OmniaScience

\title{
Measuring IC following a semi-qualitative approach: An integrated framework
}

\author{
Chiara Verbano, Maria Crema \\ University of Padova (Italy) \\ chiara.verbano@unipd.it,crema@gest.unipd.it
}

Received May 2013

\section{Abstract}

Purpose: Considering the different IC measures adopted in literature, the advantages of adopting semi-qualitative measures, and the lack of an agreed system for IC evaluation, the purpose of the paper is to analyse literature on IC measurement following a semi-qualitative approach, with the final intent to build an IC measurement framework.

Design/methodology/approach: A literature review on IC measurement system, following a semi-qualitative approach, has been conducted and analysed, in order to re-organize and synthesize all items used in previous researches.

Findings: An integrated framework emerged from this research and it constitutes an IC measurement system, created gathering and integrating different items previously adopted in literature. Each of these variables has been organized in categories belonging to one of the three main components of IC: human capital, internal structural capital and relational capital.

Originality/value: This research provides an integrated tool for IC evaluation, fostering toward a well agreed measurement system that is still lacking in literature. This framework could be interesting not only for the academic world, which in the last two decades reveals increasing attention to IC, but also for the management of the companies, that with IC measurement can increase awareness of the firm's value and develop internal auditing system to support the management of these assets. Moreover, 
it could be a useful instrument for the communication of IC value to the external stakeholders, as customers, suppliers and especially shareholders, and to investors and financial analysts.

Keywords: intellectual capital, intangible capital, measurement system, framework, semiqualitative measures

Jel Codes: O3, M1

\section{Introduction}

In literature different definitions of intellectual capital (IC) are provided. Some of them converge in the definition of IC as a set of intangible assets that enable firms to generate added value (Bontis, Dragonetti, Jacobsen \& Roos, 1999; Subramaniam \& Youndt, 2005; Reed, Lubatkin \& Srinivasan, 2006). Another aspect common with many definitions is that proposed by Stewart (1997), which defines IC as the difference between the market value and the book value of a company. Stewart (1997), Bontis (2001), Zerenler, Hasiloglu \& Sezgin 2009, Hsu and Wang (2012) emphasize a third aspect in their definition of IC, considering it as a stock of knowledge stored within the company and that can be used by employees. One of the most comprehensive definitions is provided by Granstrand (2000) which includes in IC all the intangible resources that can be considered assets, which can be purchased, combined, transformed and exploited.

Even if IC is defined in different ways, the majority of the authors recognized that it is constitutes of 3 categories: human capital (HC), which is the basis of personal knowledge of an organization residing in its employees (Bontis, 2001), internal structural capital (ISC), that is the institutionalized knowledge and codified experience that reside within the company (Subramaniam \& Youndt, 2005) and relational capital (RC) that is brands and company image and all the relationships the company has with the outside environment and from which it can gain advantages (Ngah \& Ibrahim, 2009; Bontis, Keow \& Richardson, 2000).

In the new economy based on ability to create, communicate and share knowledge, tangible and financial assets are rapidly becoming commodities that can generate at most a moderate return on investment. Extraordinary profits and dominant competitive positions are obtainable only with the intelligent use of intangible assets (Lev, 2001). In this context, to understand how a company creates value based on IC possessed becomes a central issue in management research (Bontis, 1999). However, when the firms base their competitive advantage on its intangible resources and know-how, the current financial schemes and the traditional performance measures, such as profit or cash flows are inadequate and insufficient (Bukh, 
2003). The reasons for this inadequacy depend on the fact that intangible assets usually can not be represented in the balance sheet at their purchase value, like tangible assets, because they are generated internally. Moreover, IC does not exist in itself, but is the result of a combined effect and synergy of various assets, both tangible and intangible, which makes it difficult to estimate it independently. Many researchers and scholars (e.g., Brennan \& Connell, 2000; Beattie \& Thomson, 2007) have argued that new methods and new indicators are needed to the managers and investors interested in the company's intangible assets, to provide them with most relevant information required in their decision-making processes. With the intention of providing a means of communication about the use, the allocation and the value of intangible resources, many companies have begun to integrate the traditional annual reports with new reports on their IC.

The evaluation and assessment of intangible resources becomes essential not only in the capital market and in the processes of merger or acquisition, but also to increase the efficiency of operations, to improve the motivation of employees and to support decisions of resources allocating (Crema \& Verbano, 2013). Although it is widely acknowledged the importance of IC for the economic well-being (Roos \& Roos, 1997), it still remains unsolved the problem of measuring a resource whose nature is intangible and non-financial.

For these reasons the aim of this paper is to develop a framework to integrate and complete the existing classifications for measuring IC, obtained analyzing the main measures purposed in literature following a semi-qualitative approach.

\section{Measures of Intellectual Capital}

In the literature there are many methods for the IC measurement that, according to Sveiby (2010), can be grouped in:

- Direct methods of assessment of intellectual capital, which provide an estimate of the economic value of intangible assets, identifying the various components. Once identified, they may be assessed individually or aggregated with coefficients;

- Market capitalization methods, which are based on the difference between book value and market capitalization;

- ROA-based methods, which calculate a return on tangible assets (Roa) in relation to standardized indices by sector of activity, and then determine the Roa of intangible assets by difference;

- Method of scorecard, that identifies the components of intangible assets, and generates indices and indicators collected in scorecards or graphics. 
Another possible classification of IC measurement system is based on the qualitative or quantitative approach. Qualitative measures are generally perceptive and are often used when the object of measurement or the attribute of interest is not quantifiable. Instead, especially for companies focused mostly on physical assets, the measure provides a quantitative output, such as the number of products, an amount of money or any amount of time. These measurements provide an accurate snapshot of the company, but assume that there is a precise moment in which these measures are taken. While quantitative measures are retrospective and tell us what happened, qualitative measures are based on the present and the future and they tell us what's going on.

Cañibano, Garcia-Ayuso \& Sánchez, 1999 measure the IC using several indicators divided into financial and non-financial; they highlight the following advantages for financial measures: 1 ) they are easy to use because of the availability of existing documentation, 2) they are familiar to both internal managers the company and for those who evaluate the company from outside 3) being common to many companies they allow performance benchmarking. However, the disadvantage of these measures is to be based on historical data and to be dependent on the existence and continuity of the market. Sveiby (2010) argues that a new asset as IC can not be measured through old financial indicators since its nature is essentially non-monetary. So, as the information regarding the IC could be useful to managers and provide an advantage from their use, a complete system of non-financial measures is needed since the traditional methods are no longer adequate (Brennan \& Connell, 2000); the traditional accounting system is based on historical data and focuses on monetary values, while IC is future-oriented.

Given that IC is a difficult element to measure, it is common to see the use of perceptive and qualitative measures (Kannan \& Albur, 2004; Crema \& Verbano, 2013), usually adopting Likert scale following a semi-qualitative approach. Such measures are distinguished by the completeness offered by qualitative IC measures and the possibility to aggregate and compare over time and space the measurements obtained, through statistically elaboration. By analyzing more than 100 articles in the field of IC, Kannan \& Aulbur, 2004 found that qualitative measures are among the most widely used measurement techniques. Although quantitative measures are considered more objective, there is empirical evidence that semiqualitative and quantitative measures, applied to the same intangibles, are often consistent with each other. For example, in a study of Bontis \& Fitz-Enz, 2002, who used both types of measurement, the authors found a positive association between the results of a survey and financial measures. 
Although the various advantages of semi-qualitative IC measures, in literature the contribution of different authors are not integrated together, giving a comprehensive measurement instrument that includes all components that should be considered for IC evaluation.

For this reason a literature review has been conducted in order to critically study and analyze semi-qualitative measures that can be applied for IC assessment.

\section{Objectives and methodology}

Considering different IC measures that are adopted in literature, the advantages of adopting semi-qualitative measures, and the lack of an agreed system for IC evaluation, the purpose of the paper is to analyse literature on IC measurement following a semi-qualitative approach, with the final intent to build an IC measurement framework.

In order to conduct a rigorous analysis, following the indications of Denyer \& Tranfield, 2009, Pawson (2006), Denyer Tranfield \& Van Aken, 2008 and Brereton, Kitchenham, Budgen, Turnera \& Khalil, 2007, a protocol for the systematic literature review has been generated including the following steps: a) Conceptual discussion of the problem; b) Definition of literature review questions; c) Search strategy; d) Paper selection criteria; e) Single paper analysis; f) Descriptive analysis of the extracted database; g) Synthesis and content analysis.

The literature review question was next formulated as follows: How can be measured intellectual capital, following a semi-qualitative approach?

Paper searching was carried out using mainly EBSCO, SCOPUS and ISI databases, and considering the period 2000-2012. The keywords employed for the searching phase were: "intangibles" or, "intangible assets" or "intellectual capital", combined with "measurement" or "measure" or "firm performance" or "business performance" or "survey".

For the paper selection phase the following criteria have been adopted: exclusion of duplications and conferences proceedings, exclusion of papers focused on public services, exclusion of papers that were not useful to answer to literature review questions. Referring to the latter filter, only articles adopting semi-qualitative method and with a detailed description of variables that measure IC were considered. This last criterion led to exclude $90 \%$ of literature selected in the previous phase. 
A database of 15 articles was finally obtained (tab.1).

\begin{tabular}{|c|c|c|c|c|}
\hline & Author/s & Title & Year & Journal \\
\hline 1 & $\begin{array}{l}\text { Ahmed, } \\
\text { Hussainey }\end{array}$ & $\begin{array}{l}\text { Managers' and auditors' perceptions of } \\
\text { intellectual capital reporting }\end{array}$ & 2010 & $\begin{array}{c}\text { Managerial } \\
\text { Auditing Journal }\end{array}$ \\
\hline 2 & $\begin{array}{c}\text { Bontis, Keow, } \\
\text { Richardson }\end{array}$ & $\begin{array}{c}\text { Intellectual capital and business performance } \\
\text { in Malaysian industries }\end{array}$ & 2000 & $\begin{array}{l}\text { J. of Intellectual } \\
\text { Capital }\end{array}$ \\
\hline 3 & Bozbura & $\begin{array}{c}\text { Measurement and application of intellectual } \\
\text { capital in Turkey }\end{array}$ & 2004 & $\begin{array}{l}\text { The Learning } \\
\text { Organization }\end{array}$ \\
\hline 4 & $\begin{array}{l}\text { Cabrita, } \\
\text { Bontis }\end{array}$ & $\begin{array}{l}\text { Intellectual capital and business performance } \\
\text { in the Portuguese banking industry }\end{array}$ & 2008 & $\begin{array}{l}\text { Int. J. of } \\
\text { Technology } \\
\text { Management }\end{array}$ \\
\hline 5 & $\begin{array}{l}\text { Hsu, } \\
\text { Sabherwal }\end{array}$ & $\begin{array}{c}\text { Relationship between Intellectual Capital and } \\
\text { Knowledge Management: An Empirical } \\
\text { Investigation }\end{array}$ & 2012 & Decision Sciences \\
\hline 6 & $\begin{array}{l}\text { Hsu, } \\
\text { Sabherwal }\end{array}$ & $\begin{array}{l}\text { From Intellectual Capital to Firm } \\
\text { Performance: The Mediating Role of } \\
\text { Knowledge Management Capabilities }\end{array}$ & 2011 & $\begin{array}{c}\text { IEEE Transactions } \\
\text { On Engineering } \\
\text { Management }\end{array}$ \\
\hline 7 & Huang, Wu & $\begin{array}{l}\text { Intellectual capital and knowledge } \\
\text { productivity: the Taiwan biotech industry }\end{array}$ & 2010 & $\begin{array}{c}\text { Management } \\
\text { Decision }\end{array}$ \\
\hline 8 & $\begin{array}{l}\text { Liu, Ghauri, } \\
\text { Sinkovics }\end{array}$ & $\begin{array}{l}\text { Understanding the impact of relational } \\
\text { capital and organizational learning on } \\
\text { alliance outcomes }\end{array}$ & 2010 & $\begin{array}{l}\text { J of World } \\
\text { Business }\end{array}$ \\
\hline 9 & $\begin{array}{l}\text { Montequin, } \\
\text { Fernandez, } \\
\text { Cabal, } \\
\text { Gutierrez }\end{array}$ & $\begin{array}{l}\text { An integrated framework for intellectual } \\
\text { capital measurement and knowledge } \\
\text { management implementation in small and } \\
\text { medium-sized enterprises }\end{array}$ & 2006 & $\begin{array}{l}\text { J. of Information } \\
\text { Science }\end{array}$ \\
\hline 10 & $\begin{array}{l}\text { Reed, } \\
\text { Lubatkin, } \\
\text { Srinivasun }\end{array}$ & $\begin{array}{l}\text { Proposing and testing an intellectual capital- } \\
\text { based view of the firm }\end{array}$ & 2006 & $\begin{array}{l}\text { J. of Management } \\
\text { Studies }\end{array}$ \\
\hline 11 & $\begin{array}{c}\text { Sharabati, } \\
\text { Jawad, Bontis }\end{array}$ & $\begin{array}{c}\text { Intellectual capital and business performance } \\
\text { in the pharmaceutical sector of Jordan }\end{array}$ & 2010 & $\begin{array}{l}\text { Management } \\
\text { Decision }\end{array}$ \\
\hline 12 & $\begin{array}{l}\text { Subramania, } \\
\text { Youndt }\end{array}$ & $\begin{array}{l}\text { The influence of intellectual capital on the } \\
\text { types of innovative capabilities }\end{array}$ & 2005 & $\begin{array}{l}\text { Academy of } \\
\text { Management } \\
\text { Journal }\end{array}$ \\
\hline 13 & Suraj, Bontis & $\begin{array}{l}\text { Managing intellectual capital in Nigerian } \\
\text { telecommunications companies }\end{array}$ & 2012 & $\begin{array}{l}\text { J. of Intellectual } \\
\text { Capital }\end{array}$ \\
\hline 14 & Wu, Lin, Hsu & $\begin{array}{l}\text { Intellectual capital, dynamic capabilities and } \\
\text { innovative performance of organizations }\end{array}$ & 2007 & $\begin{array}{c}\text { Int. J. of } \\
\text { Technology } \\
\text { Management }\end{array}$ \\
\hline 15 & $\begin{array}{l}\text { Youndt, } \\
\text { Subramania, } \\
\text { Snell }\end{array}$ & $\begin{array}{l}\text { Intellectual Capital Profiles: An Examination } \\
\text { of Investments and Returns }\end{array}$ & 2004 & $\begin{array}{l}\text { J. of Management } \\
\text { Studies }\end{array}$ \\
\hline
\end{tabular}

Table 1. The obtained database on IC measurement

The journals most considered are the International Journal of Technology Management, the Journal of Intellectual Capital, Journal of Management Studies and Management Decision, each with two articles. As far as time distribution is concerned, it can be observed that almost half of the papers were published in the last three years (2010-2012), showing an increasing interest in this theme. 


\section{Literature review on semi-qualitative IC measures}

The articles obtained in the database were deeply analyzed to understand and report the structure (i.e. the main constructs) and the items used in the questionnaire to measure IC.

All the papers considered recognised the three following basic components of IC: human capital (HC), internal structural capital or organizational capital (ISC) and relational capital or market capital (RC). Within each construct a limited number of items are considered and only in very few cases they are structured in grouping variables inside each construct.

In the following, items and categories of variables identified grouping the items of the questionnaires based on the object of measurement, will be presented for the three constructs, highlighting also features and differences resulting from the analysis of the database.

\section{Human capital measurement}

Combining works of different scholars, HC refers to capabilities and attitude of the employees, knowledge and competence, experience, education and training, creativity (Marr, 2005; Roos, Roos, Dragonetti \& Edvinsson, 1997; Hudson, 1993). Integrating human capital items of the various questionnaires considered the following categories can be recognised (see table 2):

- Education and training: includes all items that affect the level of education of employees, knowledge and competencies gained through the training offered by the company. Many authors (Sharabati, Jawad \& Bontis, 2010; Bontis et al., 2000; Cabrita \& Bontis, 2008; Suraj \& Bontis, 2012) insert these elements relating to training in structural capital. On the one hand, the training offered by the company to enhanced individual knowledge is an indicator of human capital; on the other hand, the fact that the company aims to increase its human capital by providing appropriate training programs is related to the structural capital. In order to avoid duplication of items in the two categories above, it was decided to follow the most common practice, which provides training as part of human capital.

- Capabilities: abilities related to how to perform their job, i.e. the know-how that can be used directly in the work environment, that includes individual skills and the experience of the employees.

- Motivation: is expressed by the alignment of employee's interests with those of the company, engaging themselves in achieving the company's objectives. This means a sense of belonging and job satisfaction that can be favoured by the incentive system.

- Versatility, creativity and innovation propensity: generally includes employee characteristics such as innovativeness, reactive and proactive skills and ability to change. 
- Internal communication and team working: the elements included in this category belong to what is called internal social capital (ISC), considered as a set of social relations, collaboration and sharing of knowledge and information among employees. According to some authors (e.g. Reed et al., 2006), the internal social capital would be a subcategory of ISC, but several other authors (Sharabati et al., 2010; Bontis et al., 2000 and others), insert it between the measures of the $\mathrm{HC}$, as the individuals and their attitudes give rise to the exchange of information and the creation of social relations inside the company. This second meaning has been followed in this work;

A detailed description of the items considered in each category can be observed in table 2 .

\section{Education and Training}

- Employees" Competence at ideal level (matching with employees work requirements and responsibilities) (Sharabati et al., 2010; Bontis et al., 2000; Cabrita \& Bontis, 2008; Suraj \& Bontis, 2012)

- Trained personnel average when compared with the sector (Sharabati et al., 2010;

Bontis et al., 2000; Cabrita \& Bontis, 2008; Suraj \& Bontis, 2012)

- Education and training employees affect the company's productivity, profitability and market value (Sharabati et al., 2010; Bontis et al., 2000; Cabrita \& Bontis, 2008; Suraj \& Bontis, 2012)

- Experts with PhD or MSc degrees (Ahmed \& Hussainey, 2010)

- Experts with professional education (Ahmed \& Hussainey, 2010)

- Company employees undertake continuous training programs every year (Sharabati

et al., 2010; Bontis et al.,2000; Cabrita \& Bontis, 2008; Suraj \& Bontis, 2012)

- The company profound lot of effort and time to update and develop the knowledge and skills of employees (Sharabati et al., 2010; Bontis et al.,2000; Cabrita \& Bontis, 2008; Suraj \& Bontis, 2012)

- The company offers training programs for employees to improve their skills (Ahmed \& Hussainey, 2010)

- Importance of investment in employees education (Bozbura, 2004)

\section{Capabilities}

- Employees are experts in their respective areas (Sharabati et al., 2010; Bontis et al., 2000; Cabrita \& Bontis, 2008; Suraj \& Bontis, 2012)

- The company has the lowest transaction cost in the sector (Sharabati et al., 2010; Bontis et al., 2000; Cabrita \& Bontis, 2008; Suraj \& Bontis, 2012)

- Experience and competence of the employees affect productivity, profitability and market value (Sharabati et al., 2010; Bontis et al., 2000; Cabrita \& Bontis, 2008; Suraj \& Bontis, 2012)

- Employees have high skills (Youndt, Subramaniam \& Snell, 2004; Huang \& Wu, 2010; Hsu \& Sabherwal, 2011; Subramaniam \& Youndt, 2005; Hsu \& Sabherwal, 2012; Reed et al., 2006)

- Employees are experts in their particular job (Youndt et al., 2004; Huang \& Wu, 2010; Hsu \& Sabherwal, 2011; Subramaniam \& Youndt, 2005; Hsu \& Sabherwal, 2012; Reed et al., 2006)

- Our employees are generally considered the best in the industry (Youndt et al., 2004; Huang \& Wu, 2010; Hsu, Sabherwal, 2011; Subramaniam \& Youndt, 2005; Hsu \& Sabherwal, 2012; Reed et al., 2006)

- Level of experience of managers (Ahmed \& Hussainey, 2010)

- Level of experience and skills of employees (Ahmed \& Hussainey, 2010) 
- Employees are able to influence managers on important problems (Reed et al., 2006)

- Employees exhibit leadership abilities (Bozbura, 2004; Reed et al., 2006)

- Level of leadership of managers (Ahmed \& Hussainey, 2010)

- Employees are focused on the quality of service provided (Reed et al., 2006)

- Employees generally give the maximum and this makes the company different from others in the field (Sharabati et al., 2010; Bontis et al., 2000; Cabrita \& Bontis, 2008; Suraj \& Bontis, 2012)

- Employees work constantly to their full potential (Sharabati et al., 2010; Bontis et al., 2000; Cabrita \& Bontis, 2008; Suraj \& Bontis, 2012)

- Employees trust and accept the goals and values (Wu, Lin \& Hsu, 2007)

- Employees devoted themselves to the organization (Wu et al., 2007)

- Employees willing to keep their membership identity (Wu et al., 2007)

- Perceived effectiveness of the remuneration system (Bozbura, 2004)

- Increasing salaries and remuneration for experts (Ahmed \& Hussainey, 2010)

- Perceived clearness of promotional policies(Ahmed \& Hussainey, 2010)

\section{Versatility, creativity and innovation propensity}

- Employees are considered creative and brilliant (Sharabati et al., 2010; Bontis et al., 2000; Cabrita \& Bontis, 2008; Suraj \& Bontis, 2012; Reed et al, 2006, Youndt et al., 2004; Huang \& Wu, 2010; Hsu \& Sabherwal, 2011; Subramaniam \& Youndt, 2005; Hsu \& Sabherwal, 2012)

- Employees usually come up with new ideas (Sharabati et al., 2010; Bontis et al., 2000; Cabrita \& Bontis, 2008; Suraj \& Bontis, 2012; Reed et al, 2006; Youndt et al., 2004; Huang \& Wu, 2010; Hsu \& Sabherwal, 2011; Subramaniam \& Youndt, 2005; Hsu \& Sabherwal, 2012)

- Compared to competitors is launched a greater number of new products ((Sharabati et al., 2010; Bontis et al., 2000; Cabrita \& Bontis, 2008; Suraj \& Bontis, 2012)

- Employees are encouraged in innovation (Ahmed \& Hussainey, 2010; Bozbura, 2004)

- Employees are satisfied with the innovation policy and programs of the company (Sharabati et al., 2010; Bontis et al., 2000; Cabrita \& Bontis, 2008; Suraj \& Bontis, 2012)

- Innovation and creativity of employees affect the company's productivity, profitability and market value (Sharabati et al., 2010; Bontis et al., 2000; Cabrita \& Bontis, 2008; Suraj \& Bontis, 2012)

- Innovation and creativity of employees affect the company's profitability (Sharabati et

al., 2010; Bontis et al., 2000; Cabrita \& Bontis, 2008; Suraj \& Bontis, 2012)

- Innovation and creativity of employees affect the company's market value (Sharabati et al., 2010; Bontis et al., 2000; Cabrita \& Bontis, 2008; Suraj \& Bontis, 2012)

- Employees develop viable solutions within a short period of time (Wu et al., 2007)

- Employees develop new ideas from past experiences (Wu et al., 2007)

- Employees are taking the necessary risks to achieve the goals (Reed et al., 2006; Ahmed \& Hussainey, 2010; Bozbura, 2004)

- Versatility: employees apply knowledge to problems and opportunities that arise in other business areas (Youndt et al., 2004; Huang \& Wu, 2010; Hsu \& Sabherwal, 2011; Subramaniam \& Youndt, 2005; Reed et al., 2006)

- Employees are able to anticipate the effects of external changes on the company (Reed et al., 2006) 


\section{Internal communication and team working}

- Employees have the ability to work together in solving problems (Youndt et al., 2004; Huang \& Wu, 2010; Hsu \& Sabherwal, 2011; Subramaniam \& Youndt, 2005; Reed et al., 2006)

- Employees share information and learn from each other (Youndt et al., 2004; Huang \& Wu, 2010; Hsu \& Sabherwal, 2011; Subramaniam \& Youndt, 2005; Reed et al., 2006)

- Employees interact and exchange ideas with people from different areas of the company (Youndt et al., 2004; Huang \& Wu, 2010; Hsu \& Sabherwal, 2011; Subramaniam \& Youndt, 2005; Reed et al., 2006)

- Employees are likely to voice their opinions in group discussion (Sharabati et al., 2010; Bontis et al., 2000; Cabrita \& Bontis, 2008; Suraj \& Bontis, 2012)

- The company gets most of its employees when they cooperate with others in company group task (Sharabati et al., 2010; Bontis et al., 2000; Cabrita \& Bontis, 2008; Suraj \& Bontis, 2012)

- Employees continually learn from the others in the company (Sharabati et al., 2010;

Bontis et al., 2000; Cabrita \& Bontis, 2008; Suraj \& Bontis, 2012)

- Employees are likely to share great new ideas within the company (Sharabati et al., 2010; Bontis et al., 2000; Cabrita \& Bontis, 2008; Suraj \& Bontis, 2012)

- Members from various departments work together to share their experience (Liu, Ghauri and Sinkovics, 2008)

- Employees are eager to share knowledge with colleagues (Liu et al., 2008)

- The relationship between employees are peaceful (Liu et al., 2008)

- Ability for employees to provide feedback to decisions makers (Ahmed \& Hussainey, 2010)

- Employees work in teams and learn from each other (Ahmed \& Hussainey, 2010; Bozbura, 2004)

- Employee participation in company meetings and conferences (Ahmed \& Hussainey, 2010)

- Employees willing to work in teams and maintain a collective identity (Wu et al., 2007)

- How adequately employees share customer information? (Reed et al., 2006)

- How adequately employees share information about competitors? (Reed et al., 2006)

- How adequately employees share resources with other business units? (Reed et al., 2006)

Table 2. Synthesis of human capital measures

\section{Internal structural capital measurement}

ISC refers to the value of the knowledge stored inside the company that can be used by employees and that regards intangible property rights, patents, organizational capital (culture, type of leadership, ability to share knowledge), knowledge stored in databases and in manuals, procedures and processes developed by employees and innovation capabilities (Kaplan \& Norton, 2004; Hsu \& Wang, 2012; Subramaniam \& Youndt, 2005; Bontis, 1998). 
A detailed description of the items considered in each category can be observed in table 3 .

\section{Strategy and organization}

- The strategy for the selection of new employees is effective (Ahmed \& Hussainey, 2010)

- The recruitment programs are comprehensive and dedicated to hiring the best candidates available (Sharabati et al., 2010; Bontis et al., 2000; Cabrita \& Bontis, 2008; Suraj \& Bontis, 2012)

- The company has a well developed reward system related to performance (Sharabati et al., 2010; Bontis et al., 2000; Cabrita \& Bontis, 2008; Suraj \& Bontis, 2012)

- The company is not a "bureaucratic nightmare" (Sharabati et al., 2010; Bontis et al., 2000; Cabrita \& Bontis, 2008; Suraj \& Bontis, 2012)

- Systems and programs affect the company's productivity, profitability and market value (Sharabati et al., 2010; Bontis et al., 2000; Cabrita \& Bontis, 2008; Suraj \& Bontis, 2012)

- The company's culture and atmosphere are comfortable and supportive (Sharabati et

al., 2010; Bontis et al., 2000; Cabrita \& Bontis, 2008; Suraj \& Bontis, 2012)

- The company supports employees constantly improving their skills and education whenever necessary (Sharabati et al., 2010; Bontis et al., 2000; Cabrita \& Bontis, 2008; Suraj \& Bontis, 2012)

- The company focuses on increasing the performance of employees (Ahmed \& Hussainey, 2010)

- The corporate culture (history, traditions) contains valuable ideas, ways of doing business, etc. (Youndt et al., 2004; Huang \& Wu, 2010; Hsu \& Sabherwal, 2011; Subramaniam \& Youndt, 2005)

- Employees have enough influence on the decisions taken within the company (Sharabati et al., 2010; Bontis et al., 2000; Cabrita \& Bontis, 2008; Suraj \& Bontis, 2012)

- The company establishes mechanisms such as informal meetings, seminars, to facilitate the exchange of knowledge between the boundaries of the various functions (Liu et al., 2010)

- The company promotes interpersonal and interdepartmental collaboration (Liu et al., 2010)

- Extent to which you retain adequate business strategy (Bozbura, 2004)

- The quality objectives are clear (Ahmed \& Hussainey, 2010)

- Level of interaction between the company and its partners (Wu et al., 2007)

- The company and its partners understand each other (Liu et al., 2010)

- The company has never had the feeling of having been deceived by partners (Liu et al., 2010)

- The company interacts with its partners through site visits and in-person meetings (Liu et al., 2010)

- Cooperation with partners has led to the achievement of planned objectives (Liu et al., 2010)

- The company is satisfied by the increase in sales resulted from the collaboration with partners (Liu et al., 2010)

\section{Intellectual Property Rights (IPR)}

- The company establishes clear strategies and procedures for the management of IPR

(Sharabati et al., 2010; Bontis et al., 2000; Cabrita \& Bontis, 2008; Suraj \& Bontis, 2012)

- The company monitors the performance of the IPR portfolio (Sharabati et al., 2010;

Bontis et al., 2000; Cabrita \& Bontis, 2008; Suraj \& Bontis, 2012)

- The company actively encourages and rewards the creation and the intensive use of IPR in order to maximize the profit (Sharabati et al., 2010; Bontis et al., 2000; Cabrita \& Bontis, 2008; Suraj \& Bontis, 2012)

- Intellectual property is considered by the top management a key asset for the creation of value (Sharabati et al., 2010; Bontis et al., 2000; Cabrita \& Bontis, 2008; Suraj \& 
Bontis, 2012)

- The company uses IPR at the highest level (Sharabati et al., 2010; Bontis et al., 2000;

Cabrita \& Bontis, 2008; Suraj \& Bontis, 2012)

- The company produces a large number of patents per year compared to its competitors(Sharabati et al., 2010; Bontis et al., 2000; Cabrita \& Bontis, 2008; Suraj \& Bontis, 2012)

- The IPR affect the company's productivity, profitability and market value (Sharabati et al., 2010; Bontis et al., 2000; Cabrita \& Bontis, 2008; Suraj \& Bontis, 2012)

- Our company uses patents and licenses as a way of storing knowledge (Youndt et al., 2004; Huang \& Wu, 2010; Hsu \& Sabherwal, 2011; Subramaniam \& Youndt, 2005; Hsu \& Sabherwal, 2012)

\section{Information infrastructure}

- Much of the company's knowledge is contained in manuals, databases, systems and procedures (Youndt et al., 2004; Huang \& Wu, 2010; Hsu \& Sabherwal, 2011; Subramaniam \& Youndt, 2005; Hsu \& Sabherwal, 2012; Reed et al., 2006)

- The company uses technology to integrate internal work processes tightly (Wu et al., 2007)

- The company keeps complete documentation of work processes (Wu et al., 2007)

- Company's documentation is digitalized Wu et al., 2007)

- Effectiveness of information management system within the company (Ahmed \& Hussainey, 2010; Bozbura, 2004)

- The information system is customized (Reed et al., 2006)

- The vital information and knowledge are protected if key employees leave the company (Reed et al., 2006)

- The processes are routinized (Reed et al., 2006)

- Level of investment in information technology (Ahmed \& Hussainey, 2010)

- Fast in achieving information (Ahmed \& Hussainey, 2010)

- No restriction to information (Ahmed \& Hussainey, 2010)

\section{Innovation capital}

- The company is considered a leader in R\&D (Sharabati et al., 2010; Bontis et al., 2000; Cabrita \& Bontis, 2008; Suraj \& Bontis, 2012; Ahmed \& Hussainey, 2010)

- More new products and innovations than the competition (Ahmed \& Hussainey, 2010)

- The company is continuously improving the production processes (Sharabati et al., 2010; Bontis et al., 2000; Cabrita \& Bontis, 2008; Suraj \& Bontis, 2012)

- The company develops and continually reorganizes itself based on R\&D (e.g., structure and responsibility) (Sharabati et al., 2010; Bontis et al., 2000; Cabrita \& Bontis, 2008; Suraj \& Bontis, 2012)

- The company follows and adopts the latest scientific and technological developments in the world (Sharabati et al., 2010; Bontis et al., 2000; Cabrita \& Bontis, 2008; Suraj \& Bontis, 2012)

- Systems and procedures are in support of innovation (Sharabati et al., 2010; Bontis et al., 2000; Cabrita \& Bontis, 2008; Suraj \& Bontis, 2012; Ahmed \& Hussainey, 2010)

- The company establishes adequate and appropriate budget for R\&D (Sharabati et al., 2010; Bontis et al., 2000; Cabrita \& Bontis, 2008; Suraj \& Bontis, 2012)

- Investment in R\&D (Ahmed \& Hussainey, 2010; Suraj \& Bontis, 2012

- The management trusts and supports R\&D (Sharabati et al., 2010; Bontis et al., 2000;

Cabrita \& Bontis, 2008; Suraj \& Bontis, 2012; Ahmed \& Hussainey, 2010)

- The R\&D affects productivity, profitability and market value company (Sharabati et al.,

2010; Bontis et al., 2000; Cabrita \& Bontis, 2008; Suraj \& Bontis, 2012)

- Extent to which new ideas are implemented (Ahmed \& Hussainey, 2010)

Table 3. Synthesis of internal structural capital measures 
For ISC the following categories can be recognized:

- Strategy and organization: set of objectives, mechanisms and organizational structures that support the work of employees and allow transforming the human individual assets in collective assets. This category includes items related to mission and strategy, organizational structure, climate and culture and human resource management practices.

- Intellectual property rights: legal mechanisms to protect corporate assets and infrastructure.

- Information infrastructure: company's ability to effectively use information and technologies to ensure the storage, distribution, and transfer of knowledge across the company.

- Innovation capital: items used to assess the know-how derived from research and development and innovation capabilities of the company, understood as that part of the structural knowledge, linked to the development of the activities and operations, is responsible for the creation of new products and services, as well as the advancement of corporate knowledge necessary for the development of future innovations.

\section{Relational capital measurement}

$\mathrm{RC}$ refers to the relation with all the stakeholders and reputation, the value of the brand and the firm image (Ngah \& Ibrahim, 2009; Przysuski, Lalapet and Swaneveld, 2004; Brennan \& Connell, 2000; Guthrie, Petty \& Ricceri, 2006; Bozbura, 2004; Ahmed \& Hussainey, 2010).

The main categories identified for this construct are:

- External collaborations: company opening to collaborations and alliances (Petroni, Venturini \& Verbano, 2012), seen as a source of learning and growth of intellectual capital;

- Customers relations: measurement of customer relationships from the point of view of accessibility to the feedback they provide to all levels of the company;

- Suppliers relations: measures the relationship with suppliers intended as a source of competitive advantage;

- Competitors and others relations: measure of the company's relationships with competitors or with other institutions (associations, local government authorities), as they are considered potential sources of innovation;

- Reputation: measure of the reputation and image of the company and the value of the brand. 
A detailed description of the items considered in each category can be observed in table 4 .

\section{External collaborations}

- The company is engaged in collaborative projects with many other companies (Sharabati et al., 2010; Bontis et al., 2000; Cabrita \& Bontis, 2008; Suraj \& Bontis, 2012)

- A high percentage of the business is done through strategic alliances (Sharabati et al., 2010; Bontis et al., 2000; Cabrita \& Bontis, 2008; Suraj \& Bontis, 2012)

- The company has numerous and diverse alliances (R\&D, production, marketing, distribution) (Sharabati et al., 2010; Bontis et al., 2000; Cabrita \& Bontis, 2008; Suraj \& Bontis, 2012)

- For the company it is important to share knowledge with partners (Sharabati et al., 2010; Bontis et al., 2000; Cabrita \& Bontis, 2008; Suraj \& Bontis, 2012)

- Strategic alliances affect the company's productivity, profitability and market value (Sharabati et al., 2010; Bontis et al., 2000; Cabrita \& Bontis, 2008; Suraj \& Bontis, 2012)

- When decisions are taken inside the company external people are consulted (Sharabati et al., 2010; Bontis et al., 2000; Cabrita \& Bonti, 2008; Suraj \& Bontis, 2012)

- Employees collaborate with strategic partners to develop external solutions (Sharabati et al., 2010; Bontis et al., 2000; Cabrita \& Bontis, 2008; Suraj \& Bontis, 2012)

- The company is able to learn and to add value through the external collaboration(Sharabati et al., 2010; Bontis et al., 2000; Cabrita \& Bontis, 2008; Suraj \& Bontis, 2012)

- The company believes that collaboration with partners is a value added (Liu et al., 2010)

- Partners provide data and documentation on technology products (Liu et al., 2010)

- The company and its partners work together by sharing technology (Liu et al., 2010)

- The desire of the partners to discuss and solve technical problems (Liu et al., 2010)

- Partners provide process technologies (Liu et al., 2010)

- The company gains experience on R\&D from its partners (Liu et al., 2010)

- The company learns new product development from its partners (Liu et al., 2010)

- The company learns new managerial practices from its partners (Liu et al., 2010)

- During years of collaboration has been developed a relationship of trust with partners (Liu et al., 2010)

\section{Customers relations}

- The company often meets clients to understand what they expect (Sharabati et al., 2010; Bontis et al., 2000; Cabrita \& Bontis, 2008; Suraj \& Bontis, 2012)

- Company gets the most possible feedbacks from customers in different circumstances (Sharabati et al., 2010; Bontis et al., 2000; Cabrita \& Bontis, 2008; Suraj \& Bontis, 2012)

- Extent to which your employees regularly visit customers (Reed et al., 2006)

- Employees regularly visit clients accompanied by top management (Reed et al., 2006)

- Level of interaction between the company and its customers (Wu et al., 2007)

- Customer data are continuously updated (Sharabati et al., 2010; Bontis et al., 2000; Cabrita \& Bontis, 2008; Suraj \& Bontis, 2012)

- An understanding of customers is spread within the company (Sharabati et al., 2010; Bontis et al., 2000; Cabrita \& Bontis, 2008; Suraj \& Bontis, 2012)

- Use of customer information across all levels of the company (Bozbura, 2004)

- Employees work with customers to develop solutions (Youndt et al., 2004; Huang, Wu, 2010; Hsu \& Sabherwal, 2011; Subramaniam \& Youndt, 2005; Reed et al., 2006)

- Benefits obtained from the relationship with customers are evaluated (Bozbura, 2004)

- The majority of the employees understand the target market and customer characteristics (Sharabati et al., 2010; Bontis et al., 2000; Cabrita \& Bontis, 2008; Suraj \& Bontis, 2012; Ahmed \& Hussainey, 2010)

- The company has significantly reduced the time to resolution of customer problems 
(Sharabati et al., 2010; Bontis et al., 2000; Cabrita \& Bontis, 2008; Suraj \& Bontis, 2012)

- The customer relationships affect productivity, profitability and market value (Sharabati et al., 2010; Bontis et al., 2000; Cabrita \& Bontis, 2008; Suraj \& Bontis, 2012)

- The company leverages needs and desires of customers constantly trying to satisfy them (Sharabati et al., 2010; Bontis et al., 2000; Cabrita \& Bontis, 2008; Suraj \& Bontis, 2012

- The company is customer-oriented (Bozbura, 2004, Ahmed \& Hussainey, 2010)

- Reduction in the number of customer complaints (Ahmed \& Hussainey, 2010)

- Customers are generally satisfied (Sharabati et al., 2010; Bontis et al., 2000; Cabrita

\& Bontis, 2008; Suraj \& Bontis, 2012; Ahmed \& Hussainey, 2010)

- Customers are loyal (Sharabati et al., 2010; Bontis et al., 2000; Cabrita \& Bontis, 2008; Suraj \& Bontis, 2012; Ahmed \& Hussainey, 2010; Bozbura, 2004)

\section{Suppliers Relations}

- The company devotes considerable time to the selection of suppliers (Sharabati et al., 2010; Bontis et al., 2000; Cabrita \& Bontis, 2008; Suraj \& Bontis, 2012)

- The company owns relatively complete data on suppliers (Sharabati et al., 2010;

Bontis et al., 2000; Cabrita \& Bontis, 2008; Suraj \& Bontis, 2012)

- The company has an information system useful and updated for the management of suppliers (Sharabati et al., 2010; Bontis et al., 2000; Cabrita \& Bontis, 2008; Suraj \& Bontis, 2012)

- The company maintains long-term stable relationships with suppliers (Sharabati et al., 2010; Bontis et al., 2000; Cabrita \& Bontis, 2008; Suraj \& Bontis, 2012)

- Relationships with suppliers are good (Ahmed \& Hussainey, 2010)

- Employees collaborate with suppliers to develop solutions (Youndt et al., 2004; Huang \& Wu, 2010; Hsu \& Sabherwal, 2011; Subramaniam \& Youndt, 2005; Hsu \& Sabherwal, 2012; Reed et al. 2006)

- Level of interaction between the company and its suppliers (Wu et al., 2007)

- Relationships with suppliers affect productivity, profitability and market value (Sharabati et al., 2010; Bontis et al., 2000; Cabrita \& Bontis, 2008; Suraj \& Bontis, 2012)

Table 4. Synthesis of relational capital measures

\section{The resulting integrated IC measurement framework}

In recent years, several authors have proposed many variables for the semi-qualitative measurement of intangibles. Each of them has also described with more or less details the aspects of IC deemed relevant in relation to the particular economic sector or geographical area of their research. Through a synthesis of all these indicators, in this section a framework for semi-qualitative measurement of IC will be proposed. This additional step is required to obtain an exhaustive set of measurement variables, considering all major aspects of IC, but at the same time excluding duplications of measurements. The developed framework for IC measurement is reported in tab.5. 


\begin{tabular}{|c|c|c|}
\hline \multicolumn{3}{|c|}{ INTANGIBLE CAPITAL } \\
\hline Human Capital & Internal Structural Capital & Relational Capital \\
\hline $\begin{array}{l}\text { Education and training } \\
\text { education } \\
\text { training } \\
\text { competences }\end{array}$ & $\begin{array}{l}\text { Strategy and Organization } \\
\text { mission and strategy } \\
\text { organizational structure } \\
\text { climate and culture } \\
\text { - human resource } \\
\text { management practices }\end{array}$ & $\begin{array}{l}\text { External Collaborations } \\
\text { - use/importance of } \\
\text { collaborations } \\
\text { - sharing knowledge, } \\
\text { experiences, problems, } \\
\text { technologies } \\
\text { - managerial practices }\end{array}$ \\
\hline $\begin{array}{l}\text { Capabilities } \\
\text { experiences } \\
\text { skills } \\
\text { leadership abilities }\end{array}$ & $\begin{array}{l}\text { Intellectual property rights } \\
\text { strategies } \\
\text { mechanisms and processes } \\
\text { use/importance of IPR }\end{array}$ & $\begin{array}{l}\text { Customer relations } \\
\text { - use/importance of } \\
\text { customers relations } \\
\text { - understanding customers } \\
\text { - sharing information and } \\
\text { problems } \\
\text { - customer satisfaction and } \\
\text { loyalty }\end{array}$ \\
\hline $\begin{array}{l}\text { Motivations } \\
\text { commitment } \\
\text { membership identity } \\
\text { incentive system }\end{array}$ & $\begin{array}{l}\text { Information Infrastructure } \\
\text { - knowledge coding } \\
\text { - investment in Information } \\
\text { management system (IMS) } \\
\text { - performance of IMS }\end{array}$ & $\begin{array}{l}\text { Supplier relations } \\
\text { - use/importance of suppliers } \\
\text { relations } \\
\text { - stability of suppliers } \\
\text { - sharing information and } \\
\text { problems }\end{array}$ \\
\hline $\begin{array}{l}\text { Versatility, creativity and } \\
\text { innovation propensity } \\
\text { (about new ideas /products, } \\
\text { problem solutions) }\end{array}$ & $\begin{array}{l}\text { Innovation Capital } \\
\text { - continuous improvement } \\
\text { - organization for innovation } \\
\text { - management commitment } \\
\text { - leadership in R\&D }\end{array}$ & $\begin{array}{l}\text { Competitors and others rel. } \\
\text { - use/importance of } \\
\text { competitors relations } \\
\text { - knowing competitors }\end{array}$ \\
\hline $\begin{array}{l}\text { Intern. comm. \& } \\
\text { teamworking (sharing } \\
\text { information, ideas, } \\
\text { knowledge, problems) }\end{array}$ & & $\begin{array}{l}\text { Reputation } \\
\text {-image } \\
\text { - brand }\end{array}$ \\
\hline
\end{tabular}

Table 5. An integrated framework for IC measurement following a semi-qualitative approach

\section{Conclusion}

As IC measurement systems found in the literature appear fragmented and unstructured, the purpose of this paper was firstly to find in the scientific literature indicators and variables used for measuring semi-qualitative IC, and to structure them into categories of variables in each of the three IC constructs (human capital, internal structural capital and relational capital). Secondly, an integrated framework synthesizing the above mentioned measures was created.

Since the new operating environment in which companies operate today, this topic is of interest not only for the academic world, which in the last two decades reveals increasing attention to this subject, but also for managers of the companies and external stakeholders, such as customers, suppliers, financial investors and shareholders, who look with interest to company resources. 
Measuring IC means becoming aware of the company's value and this is the first step to translate this intangible capital into economic value and thus into profit. Examples are the benefits arising from the price premium, the strategic position achieved by innovation leadership, by brand recognition, or by increasing customer loyalty. These are all decisive factors for the competitive advantage, deriving from the effective exploitation of intangible resources. As regards the external communication, a tool for IC evaluation, compared to the traditional financial performance parameters, offers also relevant information for outside investors and analysts.

Further developments of this research will provide validation of this framework within a sample of companies belonging to different sectors, in order to test its suitability and to improve it with refinements suggested from this testing. Moreover, after the operationalization of the proposed framework, statistical analysis such as cluster analysis and regressions would allow to describe companies, creating their profiles on the basis of intangible assets, as well as enabling the analysis of possible relations among the components of intangibles. Other variables, such as performance, strategies, company size and so on could also be studied, by linking them to the intangibles.

The theoretical framework created could also form the basis for the development of an instrument of internal auditing, to be adopted to support the evaluation, management and communication of the value of intangible assets.

\section{References}

AHMED, A.; HUSSAINEY, K. (2010). Managers' and auditors' perceptions of intellectual capital reporting, Managerial Auditing Journal, 544-860. http://dx.doi.org/10.1108/02686901011080035

BEATTIE, V.; THOMSON, S.J. (2007). Lifting the Lid on the Use of Content Analysis to Investigate Intellectual Capital Disclosures, Accounting Forum, 31: 129-163. http://dx.doi.org/10.1016/j.accfor.2007.02.001

BONTIS, N. (2001). Assessing knowledge assets: a review of the models used to measure intellectual capital, International Journal of Management Review, 3(1): 41-60. http://dx.doi.org/10.1111/1468-2370.00053

BONTIS, N.; DRAGONETTI, N.C.; JACOBSEN, K.; ROOS, G. (1999). The knowledge toolbox: A review of the tools available to measure and manage intangible resources, European management journal, 17(4): 391-402. http://dx.doi.org/10.1016/S0263-2373(99)00019-5

BONTIS, N.; FITZ-ENZ, J. (2002). Intellectual capital ROI: a causal map of human capital antecedents and consequents, Journal of Intellectual Capital, 3(3): 223-247. http://dx.doi.org/10.1108/14691930210435589 
BONTIS, N.; KEOW, W.C.; RICHARDSON, S. (2000). Intellectual capital and business performance in Malaysian industries, Journal of Intellectual Capital, 1(1): 85-100. http://dx.doi.org/10.1108/14691930010324188

BOZBURA, F.T. (2004). Measurement and application of intellectual capital in Turkey, Learning Organization, 11(4/5): 357-367. http://dx.doi.org/10.1108/09696470410538251

BRENNAN, N.; CONNELL, B. (2000). Intellectual capital: current issues and policy implications, Journal of Intellectual Capital, 1(3): 206-240. http://dx.doi.org/10.1108/14691930010350792

BRERETON, P.; KITCHENHAM, B. A.; BUDGEN, D.; TURNERA, M.; KHALIL, M. (2007). Lessons from applying the systematic literature review process within the software engineering domain, The Journal of Systems and Software, 80(4): 571-583. http://dx.doi.org/10.1016/j.jss.2006.07.009

BUKH, P. N. (2003). Commentary: The relevance of intellectual capital disclosure: a paradox?, Accounting, Auditing \& Accountability Journal, 16(1): 49-56. http://dx.doi.org/10.1108/09513570310464273

CABRITA, M.; BONTIS, N. (2008). Intellectual capital and business performance in the Portuguese banking industry, International Journal of Technology Management, 43(1-3): 212-237. http://dx.doi.org/10.1504/IJTM.2008.019416

CAÑIBANO, L.; GARCIA-AYUSO, M.; SÁNCHEZ, P. (2000). Accounting for intangibles: a literature review, Journal of Accounting Literature, 19: 102-130.

CREMA, M., VERBANO, C. (2013). The influence of technology innovation strategy on intangible assets and their impact on innovation performance, Global Innovation and knowledge Academy- GIKA 2013, University of Valencia, Spain, 9-11th July 2013.

DENYER, D.; TRANFIELD, D. (2009). Producing a Systematic Review. In D.A. Buchanan and A. Bryman (eds). The SAGE Handbook of Organizational Research Methods. pg. 670-689, London: SAGE.

DENYER, D.; TRANFIELD, D.; VAN AKEN, J. E. (2008). Developing Design Propositions through Research Synthesis, Organization Studies, 29(3): 393-413. http://dx.doi.org/10.1177/0170840607088020

GRANSTRAND, O. (2000). The shift towards intellectual capitalism, the role of infocom technologies, Research Policy, 29(9): 1061-1080. http://dx.doi.org/10.1016/S00487333(99)00070-0

GUTHRIE, J.; PETTY, R.; RICCERI, F. (2006). The voluntary reporting of intellectual capital: comparing evidence from Hong Kong and Australia, Journal of Intellectual Capital, 7(2): 254-271. http://dx.doi.org/10.1108/14691930610661890

HSU, I.; SABHERWAL, R. (2012). Relationship between Intellectual Capital and Knowledge Management: An Empirical Investigation, Decision Sciences, 43(3): 189-524. http://dx.doi.org/10.1111/j.1540-5915.2012.00357.x 
HSU, I.C.; SABHERWAL, R. (2011). From Intellectual Capital to Firm Performance: The Mediating Role of Knowledge Management Capabilities, IEEE Transactions On Engineering Management, 58(4): 626-642. http://dx.doi.org/10.1109/TEM.2011.2111455

HSU, L.C.; WANG, C.H. (2012). Clarifying the Effect of Intellectual Capital on Performance: The Mediating Role of Dynamic Capability, British Journal of Management, 23(2): 179-205. http://dx.doi.org/10.1111/j.1467-8551.2010.00718.x

HUANG, Y.C.; WU, Y.C. J. (2010). Intellectual capital and knowledge productivity: the Taiwan biotech industry, Management Decision, 48(4): 580-599. http://dx.doi.org/10.1108/00251741011041364

HUDSON, W. (1993). Intellectual capital: How to build it, enhance it, use it. New York: John Wiley.

KANNAN, G.; AULBUR, W.G. (2004). Intellectual capital: measurement effectiveness, Journal of Intellectual Capital, 5(3), 389-413. http://dx.doi.org/10.1108/14691930410550363

KAPLAN, R.S.; NORTON, D.P. (2004). Measuring the strategic readiness of intangible assets, Harvard business review, 82(2): 52-63.

LEV, B. (2001). Intangibles: Management, measurement, and reporting, Brookings Inst Press.

LIU, C.L.E.; GHAURI, P.N.; SINKOVICS, R.R. (2010). Understanding the impact of relational capital and organizational learning on alliance outcomes, Journal of World Business, 45(3): 237-249. http://dx.doi.org/10.1016/j.jwb.2009.09.005

MARR, B. (2005). Perspectives on Intellectual Capital: Multidisciplinary Insights into Management, Measurement, and Reporting. Boston: Elsevier, MA.

MONTEQUIN, V.R.; FERNANDEZ, F.O.; CABAL, V.A.; GUTIERREZ, N.R. (2006). An integrated framework for intellectual capital measurement and knowledge management implementation in small and medium-sized enterprises, Journal of Information Science, 32(6): 525-538. http://dx.doi.org/10.1177/0165551506067127

NGAH, R.; IBRAHIM, A.R. (2009). The Relationship of Intellectual Capital, Innovation and Organizational Performance: a Preliminary Study in Malaysian SMEs, International Journal of Management Innovation Systems, 1(1): 1-13.

PAWSON, R. (2006). Evidence-Based Policy: A Realist Perspective. London: SAGE publications. PETRONI, G.; VENTURINI, K.; VERBANO, C. (2012). Open innovation and new issues in R \& D organization and personnel management. The International Journal of Human Resources Management, 23(1): 147-173. http://dx.doi.org/10.1080/09585192.2011.561250

PRZYSUSKI, M.; LALAPET, S.; SWANEVELD, H. (2004). Transfer pricing of intangible property part 1: a Canadian-US comparison, Corporate Business Taxation, 5(9): 1-9.

REED, K.K.; LUBATKIN, M.; SRINIVASAN, N. (2006). Proposing and Testing an Intellectual Capital-Based View of the Firm, Journal of Management Studies, 43(4): 867-893. http://dx.doi.org/10.1111/j.1467-6486.2006.00614.x 
ROOS, G.; ROOS, J.; DRAGONETTI, N.; EDVINSSON, L. (1997). Intellectual Capital; Navigating in the New Business Landscape. New York: New York University Press.

ROOS, G.; ROOS, J. (1997). Measuring your company's intellectual performance, Long range planning, 30(3): 413-426. http://dx.doi.org/10.1016/S0024-6301(97)90260-0

SHARABATI, A.A.A.; JAWAD, S.N.; BONTIS, N. (2010). Intellectual capital and business performance in the pharmaceutical sector of Jordan, Management Decision, 48(1): 105-131. http://dx.doi.org/10.1108/00251741011014481

STEWART, T. A. (1997). Intellectual capital: The new wealth of organizations. New York: Doubleday.

SUBRAMANIAM, M.; YOUNDT, M.A. (2005). The Influence of Intellectual Capital on the Types of Innovative Capabilities, Academy of Management Journal, 48(3): 450-463. http://dx.doi.org/10.5465/AMJ.2005.17407911

SURAJ, O.A.; BONTIS, N. (2012). Managing intellectual capital in Nigerian telecommunications companies, Journal of Intellectual Capital, 13(2): 262-282. http://dx.doi.org/10.1108/14691931211225724

SVEIBY, K.E. (2010). Methods for measuring intangible assets, available online at: http://www.sveiby.com/articles/IntangibleMethods.htm (accessed March, 2013).

WU, S.H.; LIN, L.Y.; HSU, M.Y. (2007). Intellectual capital, dynamic capabilities and innovative performance of organisations, International Journal of Technology Management, 39(3): 279-296.

YOUNDT, M.A.; SUBRAMANIAM, M.; SNELL, S.A. (2004). Intellectual capital profiles: An examination of investments and returns, Journal of Management Studies, 41(2): 335-362. http://dx.doi.org/10.1111/j.1467-6486.2004.00435.x

ZERENLER, M.; HASILOGLU, S.B.; SEZGIN, M. (2009). Intellectual Capital and Innovation Performance: Empirical Evidence in the Turkish Automotive Supplier, Journal of Technology Management \& Innovation, 3(4): 31-40.

Intangible Capital, 2013 (www.intangiblecapital.org)

\section{(ब)}

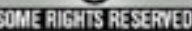

El artículo está con Reconocimiento-NoComercial 3.0 de Creative Commons. Puede copiarlo, distribuirlo y comunicarlo públicamente siempre que cite a su autor y a Intangible Capital. No lo utilice para fines comerciales. La licencia completa se puede consultar en http://creativecommons.org/licenses/by-nc/3.0/es/ 